\title{
UPACARA ADAT KEMATIAN CAWIR METUA PADA ETNIS KARO DI DESA KUTAGUGUNG KECAMATAN JUHAR \\ Oleh: \\ Kamarlin Pinem*
}

\begin{abstract}
Abstrak
Penelitian ini adalah sebuah penelitian etnografi yang dilakukan dengan mengikuti secara langsung kejadian atau peristiwa adat yaitu upacara kematian cawir metua pada masyarakat etnis Karo. Lokasi dilakukannya penelitian ini di Desa Kutagugung Kecamatan Juhar, yang memang secara kebetulan, peneliti masih menjadi saudar (kalimbubu) dari keluarga yang meningggal.

Dalam penelitian ini, ditemukan bahwa beberapa sudah terjadi perubahan oleh karena factor ekonomi, agama, waktu dan pendidikan. Selain itu juga ada perbedaan dalam pelaksanaan cawir metua rose dan erkata gendang dengan cawir metua tapi la rose dan acara gendang mentas. Perubahan dan perbedaan ini, terutama banyak yang tidak diketahui oleh generasi muda masa kini, alih-alih mau melaksanakannya, akan tetapi justru yang terjadi adalah meninggalkannya. Hal ini terlihat dalam eksistensinya sehari-hari, secara jelas tampak seolah-olah mereka tidak sanggup lagi memperhatikan tata karma yang sesuai dengan adat budaya Karo.
\end{abstract}

\section{Kata Kunci: Upacara Adat, Kematian, Cawir Metua, Etnis Karo}

\section{A. Pendahuluan}

Jika di perhatikan kehidupan masyarakat Karo, khususnya pada masa sekarang ini, ternyata mereka sudah kena pengaruh alam modernisasi dan teknologi canggih, yang tampak dalam kehidupan sehari-hari. Demikian juga dalam tindak-tanduk masyarakat Karo khususnya sudah mengalami perubahan/pergeseran. Sehubungan dengan hal itu, tampak jelas dalam segala kegiatan, demikian juga dalam pergaulan seseorang di tengah-tengah masyarakat sebagai orang Karo. Sering menurut pengamatan saya orang-orang tidak tahu lagi mana yang baik, dan yang buruk, mana yang pantas ataupun tidak pantas berdasarkan tata krama adat dan budaya Karo.

Demikian juga kalau diperhatikan pada masa sekarang ini, ternyata bahwa istilah-istilah ataupun kata-kata yang biasa dipergunakan dalam adat budaya Karo, dapat dikatakan bahwa generasi muda Karo sekarang tidak dapat lagi memecahkannya, apalagi melaksanakannya, apakah adat kematian atau adat

\footnotetext{
* Dosen Jurusan Pendidikan Geografi, Fakultas Ilmu Sosial, UNIMED
} 
perkawinan. Oleh karena itu, generasi tua sering merasa sedih melihat tindak-tanduk generasi muda yang kurang berkepribadian. Di pihak lain, generasi muda sekarang beranggapan pula bahwa generasi tua itu kuno, ketinggalan zaman di dalam Era Globalisasi ini.

Berdasarkan situasi dan kondisi yang demikian maka tujuan dari penelitian ini adalah untuk mendeskripsikannya demi kelestarian adat budaya Karo yang belakangan ini telah mengalami erosi, yang mungkin saja pada suatu saat nanti bias hilang atau lenyap dari budaya nasional jika tidak ada usaha untuk melestarikannya. Berdasarkan uraian di atas, maka sudah sewajarnya semua masyarakat Karo merenungkan kembali tentang adat budaya Karo agar dalam mengikuti zaman modernisasi dan perkembangan teknologi canggih pada masa kini, saya, anda, kita seluruhnya warga Karo dapat menunjukkan identitas sebagai orang Karo.

\section{B. Pembahasan}

\section{Upacara Adat Cawir Metua}

Berdasarkan kebiasaan masyarakat Karo malam pertama setelah seseorang meninggal, biasanya langsung diadakan keluarga (sangkep nggeluh) musyawarah atau runggu tentang pelaksanaan upacara adat kematian (cawir metua), demikian yang saya amati yang dimusyawarahkan meliputi, tentang kapan orang meninggal itu di kuburkan, apa utang adat yang dilaksanakan, apa lauk pauk yang harus dipotong, siapa-siapa yang harus diundang, bagaimana bentuk pesta, apakah semua anak-anak / cucu berpakaian adat atau rose. Anak beru lalu mengadakan pembagian tugas, mempersiapkan / mengantar undangan, menginventaris yang akan rose dan kalimbubu yang membawa ose, mencari lembu untuk pesta, mengantar undangan pesta dan sebagainya.

Hasil musyawarah atau runggu itu, pada masyarakat Karo umumnya dan masyarakat desa kutagugung pada khususnya, bahwa upacara adat cawir metua itu dapat dibagi dua jenis, yaitu cawir metua, rose dan erkata gendang, sementara satu lagi ada upacara cawir metua, tapi la rose dan gendang mentas. Beda pelaksanaan kedua acara tersebut terletak pada tahapannya, yaitu : Cawir metua, rose dan erkata gendang : semua anak-anak saudara sepupu harus rose, artinya harus berpakaian adat Karo, sedangkan cawir metua, la rose dan gendang mentas : anak-anak, cucu-cucu almarhum tidak perlu pakaian adat Karo dan lebih simpel ketimbang yang pertama tadi, tidak hanya berdasarkan perbedaan soal pakaian adat yang dipergunakan, termasuk jika, cawir metua, rose, erkata gendang, maka yang rumit harus ada dilaksanakan 
gendang naruhken tudungen, maksudnya adalah calon penerus hubungan antara keluarga almarhum dengan kalimbubu. Untuk itu tudungen biasanya adalah anak gadis kalimbubu, yakni disebut beru si ngumban dan beru puhum.

Pagi itu sebelum upacara adat dimulai di pukul gendang naruhken tudungen. Maka menarilah anak gadis beru singumban dan beru puhum bersama anak perjaka dari keluarga almarhum. Pada saat menari ini anak beru dari yang meninggal menyerahkan sirih dan perlengkapannya, agar yang menari nanti kawin dengan keluarga yang meninggal, dan sirih itu saat ini diganti dengan uang, dan bedanya dengan cawir metua, tapi la rose artinya tidak pakaian adat, maka acara naruhken tudungen atau acara menari tidak perlu ada, sehingga lebih simpel dan sederhana, biayapun lebih ringan.

Disamping yang dinaikan di atas beda pelaksanaan lain antara keduanya cawir metua itu adalah masalah tertib acara pada menari (landek). Kalau cawir metua rose dan erkata gendang adalah, gendang sukut, gendang acara rose (pengantar berpakaian adat), gendang setelah selesai rose (berpakaian adat), gendang kalimbubu dan terakhir gendang anak beru dan berbeda jika dibandingkan dengan urutan cawir metua, la rose dan gendang mentas yaitu: gendang suhut, gendang kalimbubu dan gendang anak beru.

Pada malam musyawarah itu juga ditetapkan sesuai dengan adat cawir metua la rose, untuk lauk pauk pengadaan daging di putuskan erbante, artinya daging dibeli di tempat penjualan daging, karena bisa lebih sempurna yaitu motong, artinya hewan di beli langsung dan dipotong sendiri dan biayanya lebih besar. Pada musyawarah tersebut dapat saya amati ada perbedaan menonjol, jika acara cawir metua rose dan erkata gendang, ada harus dipenuhi yaitu adat motong yang terdiri dari tulan putor untuk kalimbubu. Tulan putor ialah bagian daging paling baik untuk kalimbubu, daging paha untuk diberikan kepada kalimbubu pada akhir acara. Bagian ekor untuk anak beru, setelah kalimbubu menerima tulan putor, maka kalimbubu menyerahkan bagian ekor kepada anak beru, sedangkan cawir metua la rose, gendang mentas tidak mutlak dilaksanakan.

Tahap berikut yang dibicarakan pada musyawarah tersebut adalah menentukan waktu penguburan, karena penguburan dilakukan secara agama yang dianutnya, Kristen maka saat membicarakan waktu penguburan itu diikut sertakan pejabat agama ikut runggu. Menentukan waktu penguburan itu penting sebagai dasar anak beru menyusun acara. Acara penguburan dilakukan besoknya, di pekuburan orang Kristen, berikunya sesuai 
dengan kesepakatan keluarga (sangkep nggeluh), maka anak beru membuat surat undangan dengan judul Berita Ceda Ate, dan dalam surat itu dicantumkan pesan sesuai dengan hasil musyawarah, yaitu : cawir metua, la rose dan gendang mentas. Juga dibicarakan susunan acara menari oleh anak beru, acara cawir metua la rose, yaitu: gendang mentas.

Adapun urutan acara menari pada adat tersebut dapat digabungkan menjadi 3 bagian, yaitu :

\section{1) Gendang Suhut}

Urutan gendang suhut ialah :

- Menari (landek) suhut, diikuti anak beru, di sinilah suhut menyampaikan kata-kata pengalo-ngalo (kata sambutan)

- Menari sembuyak, ngalo-ngalo suhut (disambut suhut)

- Menari semua, ngalo-ngalo suhut

- Menari sepemeren, sipariban, sedalanen dan sepengalon ngalo-ngalo suhut.

- Menari kepala desa, ngalo-ngalo suhut

- Menari teman seiman, ngalo-ngalo suhut

Selesai gendang suhut, acara dilanjutkan sesuai ketentuan yang berlaku di daerah bersangkutan dan diputuskanlah ndungi utang adat yang meninggal diselesaikan setelah selesai gendang suhut, dan setelah utang adat selesaikan, acara dilanjutkan gendang kalimbubu.

\section{2) Gendang Kalimbubu}

Urutan menari dalam gendang kalimbubu ialah sebagai berikut:

- Menari kalimbubu sekaligus atau dalam beberapa group sesuai musyawarah dan ngalo-ngalo suhut (disambut suhut). Pada saat inilah penayep (kain putih) di berikan kalimbubu kepada yang meninggal

- Menari puang kalimbubu, sekaligus puang ni puang kalimbubu, ngalo-ngalo suhut dan kalimbubu.

Pada saat itulah kain putih (penayep) diletakkan di peti jenazah sebagai penghormatan terakhir kalinya. Namun sebelum dilaksanakan, kalimbubu memberikan sepatah dua kata sebagai kata-kata penghiburan terhadap keluarga (anak-anak dan saudara ipar saya) semoga tabah menghadapi duka yang diterima, dan serahkan persoalan yang dihadapi kepada Tuhan Yang Maha Esa, dengan itu sebagai penghiburan berdasarkan Firman Tuhan.

Kitap pengerana : nggeluh enda erpaksa-paksa, lit paksa meriah ukur, janah lit ka paksa la meriah ukur. Artinya : hidup ini, kadang suka cita, dan kadang duka cita secara bergiliran dihadapi manusia sebagai ciptaan Tuhan. Oleh karena itu bersabarlah bere-bere kami dan seluruh 
keluarga, ada rencana Tuhan lebih baik terhadap keluarga ini.

Setelah selesai ucapan tersebut, disambung oleh saudarasaudara lainnya selaku kalimbubu. Menurut tokoh adat di Desa Kutagugung, Kapiten Perangin-angin, Penayep ialah: kain putih yang merupakan kebiasaan orang Karo diberikan kalimbubu sebagai perlakuan terakhir dilakukan kepada yang meninggal adalah: sebagai pakaian yang pantas menghadap pengulu kuburan, keperluan sehari-hari kepada keluarga yang ditinggalkan berupa beras dan ayam. Ini adalah gambaran yang dilakukan Yesus Kristus kepada yang meninggal dalam namanya, sesuai kesaksian injil dalam sangkep nggeluh jemaat GBKP, Yesus Kristus termasuk tegun kalimbubu. Dengan demikian Yesus Kristuslah yang memberikan penayep kepada ngawan GBKP yang meninggal, berarti: Tuhan Yesus memberinya pakaian yang pantas untuk menghadap Allah. Berdasarkan kesaksian injil, pakaian yang diberikan Yesus Kristus inilah menjaminnya diterima Allah Bapa di Surga. Sebagaimana kalimbubu dalam adat memberikan wis dagangen (kain putih) kepada anak berunya yang meninggal bukan berdasarkan kebaikan atau jasa anak Beru-nya tersebut kepadanya, melainkan karena kasihnya semata, demikian juga berdasarkan kesaksian injil, Yesus Kristus memberikan pakaian kepada yang meninggal dalam namaNya, bukan karena kebaikannya tetapi karena kasihNya semata. Di samping kain putih (dagangen), kalimbubu dalam adat juga memberikan penayeb kepada anak beru-nya yang ditinggalkan si almarhum berupa keperluan hidup sehari-hari, merupakan gambaran dari janji Allah.

Demikian pula setelah selesai kalimbubu menari dan penyerahan penayep, maka tiba giliran menari dari kalimbubu yang disebut puang kalimbubu yakni paman. Pada saat kalimbubu menari maka pihak suhut ngalo-ngalo dan kalimbubu (menyambut). Pihak puang kalimbubu juga secara bergantian memberikan sepatah-dua kata kepada anak beru saya yakni sebagai keluarga duka, setelah selesai menari hal sama juga dilakukan puang kalimbubu memberikan kain putih (dagangen) sebagai penayeb kepada jenazah, prosesnya sama dengan yang dilakukan oleh kalimbubu di atas.

\section{3) Gendang Anak beru}

- Menari anak beru, ngalo-ngalo suhut

Pada saat menari anak beru secara gantian mengucapkan sepatah-dua kata-kata penghibur pada keluarga yang ditinggalkan sama dengan pada acara gendang suhut dan gendang kalimbubu di 
atas, pada giliran terakhir acara adalah anak beru, yang merupakan semua anak beru yang empat marga.

- Anak beru menteri dan anak beru singikuri, ngalo-ngalo suhut.

Tempo dulu setelah selesai menari (landek), anak beru langsung menuju peti jenazah mengantarkan pemberangkatan ke kuburan. Tetapi sekarang ini, umumnya tidak demikian lagi, akan tetapi diaturkan penyerahannya kepada pejabat Gereja, yakni Agama Protestan karena yang melaksanakan penguburan adalah pihak Gereja. Pihak Gereja melakukan liturgi penguburan dan diikuti oleh sanak keluarga.

Pada besok harinya, yaitu pada upacara adat, maka sesuai dengan kebiasaan di desa itu, upacara dilakukan di jambur dan berbeda dengan etnis Toba dilaksanakan di rumah duka, sesuai dengan kebiasaan seperti yang diutarakan pada hal di depan ada acara untuk mengangkat peti jenajah dari rumah ke tempat acara di jambur, yaitu kalimbubu mengangkat bagian kepala, sembuyak di bagian tengah dan anak beru di bagian kaki jenajah. Sebelum pengangkatan jenajah maka jumlah anak beru almarhum membuat foto (dokumen keluarga) antara keluarga, cucu, cucu almarhum.

Pada malam berikutnya setelah selesai acara adat tepat pukul $16^{00} \mathrm{Wib}$, maka acara penguburan sesuai dengan musyawarah sebelumnya (runggu) keluarga atau sangkep nggeluh, maka acara di serahkan kepada gereja (Gereja Kristen Batak Karo) untuk acara liturgi pemakaman, sesuai dengan kebiasaan jemaat kristen maka dalam acara liturgi pihak gereja meminta keluarga untuk duduk mengelilingi peti jenazah sebelum upacara dimulai. Biasanya acara seperti yang saya amati yang membawa acara ialah Pendeta/Sintua guna melaksanakan kegiatan itu. Dalam acara Pendeta meminta keluarga tidak ada lagi yang menangisi tetapi bernyanyi dalam nama Tuhan, dengan maksud dan pengharapan semoga Allah Bapa di Surga menempatkan jiwa/roh yang meninggal di tempatkan di sisinya sesuai dengan amal bakti ketika almarhummasih hidup. Berikutnya setelah acara kebaktian selesai, Pendeta seraya berucap kebaktian telah selesai dan sambil bertanya apakah ada benda yang mau dimasukkan atau diambil dari dalam peti, jika tidak ada maka menyuruh anak beru, agar peti ditutup dan berangkatlah kami beserta seluruh keluarga dan di iringi oleh jemaat kristen untuk mengantar jenazah ketempat peristirahatan sementara untuk menuju rumah Bapa di surga. Dan peti jenazah diangkat oleh anak beru kedalam pickup sebagai alat transportasi kekuburan, jarak yang ditempuh $\pm 2 \mathrm{~km}$ dari jambur.

Kalau dulunya di angkat dan diarak oleh manusia, maka sekarang diantar kepekuburan menggunakan kendaraan roda 
empat dan di iringi oleh semua anggota keluarga adalah merupakan hal biasa. Demikian juga peti jenazah langsung dibawa kepekuburan, jauh berbeda dengan kebiasaan tempo dulu yang harus berhenti empat kali. Dan dalam acara penguburan anggota keluarga saya ada yang khusus karna tempat kuburannya dilakukan di luar kuburan umum, yaitu dilakukan di perladangan almarhum sesuai dengan permintaan keluarga (suami). Kebiasaan seperti itu memang sudah sering dilakukan di Kutagugung dan bukan dilarang. Kuburanya sehari setelah meninggal langsung di buatkan oleh anak beru terbuat dari keramik dan lokasinya dekat ke jalan raya. Dalam pembuatan kuburan masyarakat Karo seyogianya dilakukan oleh kalimbubu dan di ikuti oleh anak beru kalau tidak dibuat dari semen/keramik artinya langsung keliang kubur, sekarang ini bukan rahasia umum biasanya pengorekkan tanah di upahkan sama orang lain, artinya atas kebijaksanaan anak beru, yang kononnya kalau dahulu sangat penting dilakukan.

Setelah sampai di perkuburan yang dimaksud, maka acara liturgi pemakaman kembali dilakukan oleh Pendeta dimana sebagai kata pengantar dan acara penguburan diambil dari ayatayat kitab suci yang mengambarkan manusia berasal dari tanah dan harus kembali ke tanah. Manusia ciptaan Tuhan dan Ia berhak kapan mengambilnya, demikian yang saya kutib acara liturgi yang dibawa oleh Pendeta dalam liturgi tersebut. Dalam acara liturgi maka saya amati adalah acara penaburan bunga di atas pusara almarhum, yang dulu dilakukan dalam acara merkat bacir, setelah empat hari kemudian. Dan sekarang untuk menghemat waktu seperti yang diuraikan pada halaman sebelumnya lazim langsung dilakukan pada hari itu juga.

Acara diatur oleh anak beru, dengan urutan : dimulai oleh suhut, disusul disusul kalimbubu dan terakhir oleh anak beru. Setelah selesai acara tabur bunga, maka anak beru menyampaikan pengumuman sebagai berikut: Besok pagi ada acara menyiram kuburan dengan air dingin di pusara almarhum (merkat bacir). Dan saya amati, acara ini segaja dilakukan untuk menghemat waktu baik dari keluarga maupun jemaat gereja. Berikutnya anak beru juga mengumumkan dua hari kemudian acara memberikan kata-kata penghiburan oleh jemaat gereja terhadap anggota keluarga yang di tinggalkan, bertempat di rumah duka, dengan pengharapan semua jemaat gereja dan anggota keluarga harap maklum dan menyediakan waktunya untuk mengambil bagian. Pada akhir acara di buat doa bersama sebagai penutup dan anggota keluarga dapat kembali ke rumah.

Kalimbubu berkewajiban ikut hadir dalam acara penghiburan (ngapuli) pada hari yang telah di tentukan itu, 
demikianlah saya rasakan tugas dan tanggung jawab sistem kekerabatan yang dari dulu dipegang teguh oleh masyarakat Karo. Namun sebelum acara ngapuli tersebut, besok harinya setelah upacara pemakaman itu keluarga inti (sangkep nggeluh) berangkat menuju kuburan untuk menyiram kuburan dengan air dingin seperti yang diungkapkan oleh anak beru sehari sebelumnya atau pada upacara pemakaman. Pagi-pagi pukul $08^{00}$ Wib kami menuju kuburan atau pusara keluarga. Pada saat itu kembali rasa haru dan pilu terkenang kembali tentang riwayat hidup almarhum, terlebih setelah anak-anak almarhum (bere) menangis terisak-isak, baik yang laki-laki maupun yang perempuan. Pada acara menabur/menyiram air dingin juga dilakukan secara bergantian dimulai oleh suhut, disusul kalimbubu dan ditutup oleh anak beru. Pada acara terakhir juga sesuai dengan kebiasaan orang Kristen termasuk di kuburan diadakan doa bersama yang dibawakan salah seorang kalimbubu, yang membawa doa dan sekaligus sebagai penutup. Setelah selesai acara, kami kembali ke rumah dan bertemu/berkumpul di jambur untuk acara terakhir dalam kebiasaan masyarakat Karo dalam acara kematian, yaitu: musyawarah (runggu sepulang dari merkat bacir) namun biasanya dilakukan setelah makan siang.

Dalam musyawarah runggu utang ido, intinya ialah: untuk membicarakan biaya penguburan dan keadaan keluarga (suami) yang akan ditinggalkan. Dulu, jika keduanya (orang tua) dari anakanaknya meninggal dunia, maka harta-hartanya dibongkar, umpama: berapa ladangnya, berapa ekor kerbau, barang-barang bergerak / tidak bergerak dan lain-lain.

\section{Perbedaan Pelaksanaan Upacara Kematian Cawir Metua}

Berdasarkan uraian upacara kematian cawir metua di atas, maka perbedaan pelaksanaan cawir metua rose dan erkata gendang dengan cawir metua tapi la rose dan acara gendang mentas, adalah sebagai berikut:

a. Pada cawir metua la rose, artinya utang adat yang dilaksanakan adalah cawir metua (lengkap), tetapi anak-anak almarhum, termasuk cucu-cucunya tidak rose (tidak berpakaian adat) sebagaimana semestinya jika cawir metua rose. Memang dari segi kepraktisan, sangat praktis dan lebih ringan, sebab jika rose paling tidak semua kalimbubu sibuk, karena sesuai dengan adat cawir metua, pihak kalimbubu harus menyediakan pakaian adat (ose) anak berunya, dan rumitnya jika kalimbubu tidak punya pakaian adat (ose), maka kalimbubu harus rental (sewa) pakaian tersebut. Jadi saya kira selain sibuk juga pengeluaran akan bertambah. 
b. Karena tidak rose (pakaian adat), dampaknya tidak ada gendang naruhkan tudungan. Seperti yang penulis paparkan pada cawir metua rose, maka ada acara gendang naruhkan tudungen, artinya anak gadis kalimbubu harus menari dengan anak lajang suhut yang melambangkan generasi penerus hubungan dengan kalimbubu. Tapi cawir metua la rose, tidak merupakan suatu keharusan di lakukan. Atas dasar itu, penulis melihat lebih sederhana dan praktis untuk dilakukan.

c. Utang adat cawir metua rose dengan utang adat cawir metua la rose dari segi jumlah materi dan benda yang dilakukan hampir sama, hal ini penulis lihat pada hasil pengamatan sewaktu dilakukan terhadap upacara dan hasil dialog penulis dengan tokoh-tokoh adat tidak ada perbedaan. Hanya saja dari acara gendang urutan-urutannya lebih sederhana dan lebih simpel pada acara cawir metua la rose, contoh tidak ada gendang sebelum rose, tidak ada gendang setelah rose dan tidak ada gendang naruhken tudungen (menari putri paman dan anak almarhum). Khusus untuk utang adat tulan putur, seperti yang saya amati, seyogianya di terima dan dibawa oleh kalimbubu pulang ke rumahnya, tapi saya lihat dan kebetulan posisi saya dengan saudara-saudara yang lain tidak melakukannya, tetapi memberikannya kepada suhut dengan mengucapkan udah kami terima dan kami serahkan kepada kalian masaklah dan nanti pada upacara makan malam, samasama kita nikmati.

d. Jika cawir metua la rose, pada malam sebelum upacara adat dilakukan, tidak ada acara gendang nangkih seperti lazimnya harus dilakukan jika cawir metua rose, satu hal yang saya lihat setelah selesai runggu adat (musyawarah) maka pengganti acara gendang nangkih diserahkan kepada Dewan Gereja untuk membuat acara secara gereja yang almarhum dalami semasa hidupnya. Dan pada acara Gereja itu saya selaku kalimbubu ikut di dalamnya. Pihak Gereja menyusun tertib acara sesuai dengan lembaga-lembaga yang ada pada Gereja itu secara bergantian memberikan sepatah dua kata guna memberikan kata-kata penghiburan kepada keluarga dan termasuk pihak Gereja memberikan giliran kepada kalimbubu.

\section{Faktor Yang Mempengaruhi Perubahan}

Adapun faktor-faktor yang mempengaruhi perubahan itu adalah sebagai berikut:

a. Pengaruh Agama.

Yang dimaksud agama ialah agama Islam dan Kristen dan pengaruhnya perlakuan terhadap orang mati berdasarkan kepercayaan "tendi menjadi begu", sudah tidak berlaku lagi. Titik 
berat perlakuan terhadap orang mati, ialah : berdasarkan imannya (agama atau dasar kepercayaannya kepada Allah). Contoh: mayat masih ditangisi (ngandung) tapi bukan lagi suatu keharusan seperti tempo dulu mayat harus ditangisi, artinya sambil menangis harus melantunkan kata-kata kesedihan dengan nada sendu yang mengundang tangis pendengarnya. Tempo dulu mayat harus dingandungi merupakan keharusan dan aib bagi menantu perempuan jika tidak pandai meratapi mertuanya yang meninggal. Sekarang cenderung hilang, berganti-ganti yang menangis, yakni menangis tanpa melantunkan kata-kata. Sebagai mana dalam Firman Tuhan mengatakan: menangis-nangislah, tapi dalam nama Tuhan. Jadi berkat kepercayaan/keyakinan yang berduka cita, maka penulis melihat dimasyarakat Karo pada umumnya, dan masyarakat desa kutagugung pada khususnya dalam hal menangis banyak sekali perubahannya, artinya ada keyakinan manusia adalah ciptaan Tuhan dan kembali kepada Tuhan.

\section{b. Pengaruh Ekonomi}

Pertimbangan ekonomi/besarnya biaya yang harus dikeluarkan akan mempengaruhi upacara cawir metua la rose. Contoh: pakaian adat (rose) jika tidak punya, tidak perlu lagi rental (sewa), manusia sekarang cenderung berfikir praktis dan ekonomis, baik dari segi biaya maupun faktor waktu, dan jika rose lengkap, maka tudungen juga akan dilaksanakan (putri paman menari bersama putra suhut almarhum), dimana dalam acara gendang tudungen itu biasanya yang menari minimal 3 pasang dan sewaktu menari mereka harus disumbang (di cokong) atau pengertian lain diberikan uang. Biaya cawir metua biayanya cenderung lebih besar di bandingkan dengan cawir metua la rose.

\section{c. Pengaruh Waktu}

Masyarakat sekarang sibuk, segala sesuatu selalu di ukur dengan uang. Perhitungan waktu juga banyak mempengaruhi upacara kematian (cawir metua). Contoh, kalau tempo dulu upacara ngamburi lau simalem-malem menabur kuburan dengan air dingin atau menabur bunga, dilakukan setelah empat hari di makamkan, sekarang tidak terikat ketentuan hari bahkan sudah umum dilakukan keesokkan harinya. Bahkan untuk menabur bunga sekarang langsung di taburkan pada hari penguburannya. Perbedaan itu sedemikian nyata dan terasa, karena sekitar 20 tahunan yang silam acara tersebut masih wajar dilaksanakan. Tetapi sekarang, pad waktu upacara penguburan keluarga, langsung saat itu juga penaburan bunga di lakukan keluarga atas prakrasa jemaat Gereja. Adapun pergeseran kebiasaan dilakukan karena pertimbangan waktu. Jika besok harinya atau hari tertentu dilakukan sudah sulit mengumpulkan orang termasuk keluarga 
karena alasan kesibukkan, malah jemaat gerejapun ikut berdalih kesibukkan (hari kerja) dan bukan rahasia lagi pihak gereja pun terpengaruh oleh pertimbangan waktu dan sebagainya. Manusia sekarang sangat menghargai betapa pentingnya waktu dan menurut pengetua Gereja bahwa apa yang diuraikan di atas merupakan fakta yang harus disesuaikan dengan situasi dan kondisi sekarang.

\section{d. Pengaruh Pendidikan.}

Semakin tinggi pendidikan masyarakat atau pengalaman masyarakat, maka masyarakat semakin rasional dalam mengerjakan sesuatu kegiatan. Masyarakat sekarang baik di perkotaan maupun di pedesaan, termasuk masyarakat desa kutagugung dalam pelaksanaan upacara adat (cawir metua) telah banyak mengadakan perubahan/pergeseran karena mereka sadar akan tuntutan zaman dan pengaruh perkembangan teknologi, semakin cepat mempengaruhi pola pikir masyarakat yang ada dipedesaan karena ruang dan jarak semakin tak berarti, artinya informasi-informasi di suatu perkotaan begitu cepat bisa diketahui oleh masyarakat di pedesaan sehingga terpengaruh terhadap perilaku masyarakat tersebut.

\section{Kesimpulan dan Saran}

1. Kesimpulan

Telah terjadi perbedaan dan perubahan pelaksanaan upacara kematian cawir metua, akan tetapi yang masih dipertahankan adalah:

a. Pertama sekali anak beru menanyakan kepada kalimbubu atau puang kalimbubu apakah utang adat orang yang meninggal sudah sampai kepada kalimbubu dan anak beru, apakah utang adat itu sudah benar? Karena utang adat itu demikian sakralnya, jika tidak sampai sama kalimbubu atau anak beru bisa-bisa menjadi cemohan bagi keluarga dan jangan-jangan disebut tidak beradat, makanya pihak keluarga yang meninggal harus betul-betul memperhatikannya.

b. Kedua dalam musyawarah itu dibicarakan hutang-piutang yang meninggal, baik dengan keluarga, maupun tetangga, pada pembicaraan anak beru dengan kalimbubu menyatakan tidak ada hutang-piutangnya. Memang dari fakta kalaupun kehidupannya di desa, kegiatannya adalah bertani, tapi karena selama masa hidupnya boleh dibilang termasuk rajin, tekun bekerja maka kehidupannya boleh di bilang berkecukupan dan terlebih anak-anaknya semua bekerja dan semuanya berada di luar desa.

c. Ketiga, dibicarakan biaya-biaya selama perobatan dan seluruh biaya pesta penguburan, menurut taksasi anak beru, ternyata 
biaya penguburannya mencapai sepuluh juta rupiah dan uang sumbangan dari semua keluarga mencapai sebelas juta lima ratus ribu rupiah, berarti ada kelebihan sekitar satu juta lima ratus ribu rupiah, berkat bantuan dari semua keluarga.

d. Keempat dibicarakan adalah tempat tinggal abang ipar, dan pembicaraan antara anak beru dan kalimbubu diputuskan tetap tinggal di desa kutagugung dan tetap menetap dirumahnya, tidak ada dipungkiri dalam keluarga tanpa membedakan/deskriminasi gender, jika yang meninggal adalah perempuan, maka suaminya menjadi masalah dalam rumah tangga. Fakta menyatakan kaum laki-laki dalam peran sebagai kepala rumah tangga selalu menjadi masalah, terutama menggantikan peran/fungsi sebagai ibu rumah tangga, terutama memasak, memang tidak bisa dipungkiri, kadangkadang menonjol keangkuhan sebagai laki-laki, tetapi yang pasti abang ipar dalam hal ini tetap berada di desa. Menurut kenyataan pada orang Karo sering dilakukan keluarga mencari calon pengganti (istri), karena yang menjadi masalah jika dalam keluarga yang meninggal itu duluan adalah perempuan dan mungkin juga pada etnis yang lain menjadi masalah yang sama, sehingga keluarga secara bersama berupaya mencari calon pengganti.

\section{Saran}

Berikutnya, usaha-usaha pembinaan terhadap generasi muda menurut hemat saya terasa kurang, baik dari pihak orang tua maupun dari pakar-pakar adat budaya Karo dan dari tokoh-tokoh adat boleh di bilang hampir tidak ada. Demikian pula dari pihak orang tua sendiri sudah kurang tanggap dan mereka tidak tahu lagi secara tepat tentang seluk-beluk adat itu, bahkan ada pula orang beranggapan bahwa adat istiadat itu tidak perlu lagi di wariskan kepada generasi muda. Terutama pada generasi muda masa kini dalam eksistensinya sehari-hari, secara jelas tampak seolah-olah mereka tidak sanggup lagi memperhatikan tata karma yang sesuai dengan adat budaya Karo. Menurut saya, bahwa keadaan ini terjadi oleh karena banyak anak muda telah lama meninggalkan kampung, dan banyak anak muda sekarang lahir dan dibesarkan bukan di daerah Karo, tetapi di kota-kota dan di daerah-daerah Indonesia lainnya.

\section{Daftar Pustaka}

Bangun, Payung, 1981. Pelapisan Sosial di Kabanjahe Desertasi, Universitas Indonesia.

Bangun, Tridah. 1986. Manusia Batak Karo. Jakarta; Inti Idayu Press. 
Barus, UC. 1995. Sejemput Adat Budaya Karo, Medan (Tanpa penerbit).

Fahruddin Chalida. 2008. Perubahan Sosial Budaya. Bahan Kuliah Pasca Sarjana UNIMED.

Garna, Judistira, 1992. Teori-Teori Perubahan Sosial, Bandung. Pascasarjana UNPAD.

Haviland, William A. 1985. Antropologi (terjemahan) Jilid 1 dan 2. Jakarta; Erlangga.

Ihromi, T.O. (editor). 1984. Pokok-Pokok Antropologi Budaya. Jakarta; Gramedia.

Kaplan, David. Mannes, Alberth. 1999. Teori Budaya (terjemahan): Yogyakarta; Pustaka Pelajar.

Koentjaraningrat, 2007. Manusia dan Kebudayaan di Indonesia. Jakarta: Jembatan. , 1982. Masalah-Masalah Pembangunan, Bunga Rampai Antropologi Tarapan, Jakarta; LP3ES. 1985. Beberapa Pokok Antropologi Sosial, Jakarta; Dian Rakyat.

Lauer. Robert H. 2003. Perspektif Tentang Perubahan Sosial, Jakarta, Rineka Cipta.

Lawang, Rokerto MZ. 1985. Sosiologi. Modul 1-9. Jakarta. UT.

Moleong, Lexy J. 2009. Metodologi Penelitian Kualitatif. Bandung, Rosda.

Pelly Usman, Menanti : Asih. 1994. Teori-Teori Sosial Budaya. Jakarta; Dikti.

Prinst Darwan, Prinst Darwin. 1985. Sejarah Kebudayaan Karo, Jakarta; Grama.

Prinst Darwan, 2004. Adat Karo. Medan : Bina Media

Sairin, Sjafri, 2002. Perubahan Sosial Masyarakat Indonesia. Yogyakarta; Pustaka Pelajar.

Sembiring, Bebas, 2008. Musik dalam Upacara Perkawinan Adat Masyarakat Karo: Fungsi Gendang Laradat Pasca Acara Nganting Manuk. Tesis. Pasca Sarjana Unimed.

Soekanto, Soerjono, 1984. Teori-teori Tentang Perubahan Sosial, Jakarta, Ghalia Indonesia.

Sugiyono, 2009. Memahami Penelitian Kualitatif. Bandung: Alfabeta.

Sztompka, Piotr. 2007. Sosiologi Perubahan Sosial. Jakarta, Prenada. 